\title{
Editorial: The Power of Implicit Theories for Learning in Different Educational Contexts
}

\author{
Yves Karlen $^{1 *}$ and Silke Hertel ${ }^{2}$ \\ ${ }^{1}$ University of Applied Sciences and Arts Northwestern Switzerland, Windisch, Switzerland, ${ }^{2}$ Heidelberg University, Heidelberg, \\ Germany
}

Keywords: implicit theories, mindsets, self-concept, beliefs, intervention, stereotypes, motivation, self-regulation

Editorial on the Research Topic

The Power of Implicit Theories for Learning in Different Educational Contexts

\section{INTRODUCTION}

Over the last few decades, members of the field of (educational) psychology have discussed how implicit theories (or mindsets) about one's abilities build an important "meaning system" that can set different learning trajectories and prime particular learning behaviours. For example, these theories might explain why certain students thrive when facing challenges while others languish. Implicit theories are defined as core assumptions about personal abilities or attributes. They can be characterised along a continuum that ranges from an incremental theory (growth mindset), which maintains that abilities can be developed, to an entity theory (fixed mindsets), which views abilities as relatively fixed and unchangeable. However, due to the increasing attempts to replicate previous effects reported for implicit theories, researchers have paid more attention to the questions of whom, why, and under what conditions the effects of an incremental theory (growth mindset) can be expected (Sisk et al., 2018; Yeager and Dweck, 2020; OECD, 2021).

Researchers use questionnaires and alternative assessment methods (e.g., neuroscience, interviews) to understand implicit theories as they apply to different age groups (Mangels et al., 2006; Compagnoni et al., 2019). Thus, paying attention to how and which implicit theories are measured to compare results is important. This is especially important since individuals can simultaneously hold various implicit theories that concern different abilities. For example, implicit theories can address domain-general implicit theories (e.g., intelligence, willpower) or domain- or ability-specific implicit theories (e.g., self-regulated learning, math). Over the last few years, some researchers have argued that domain-specific implicit theories may be better suited for predicting domain-specific behaviour than domain-general implicit theories (Gunderson et al., 2017; Hertel and Karlen, 2021). It might therefore be beneficial to examine both domain-general and domain-specific theories together. Consequently, examining how findings from one domain apply to another is essential. This circumstance calls for studies that aim to replicate previously reported results. Finally, researchers have empirically demonstrated that (short) interventions could change implicit theories (Bostwick and Becker-Blease, 2018; Burnette et al., 2020; Lee et al., 2021). However, the approaches and the effects of those interventions are heterogeneous. One reason for these inconsistent results might be that interventions are likely to be stronger or weaker for different groups and contexts. Therefore, more (intervention) studies that explore the potential for different implicit theories in diverse populations and different cultural contexts and with different approaches must be conducted. 
TABLE 1 | Overview of all 14 studies contributing to the Research Topic.

\begin{tabular}{|c|c|c|c|c|c|}
\hline Authors & $\begin{array}{l}\text { Implicit theories } \\
\text { (mindsets) }\end{array}$ & Sample & Research focus & $\begin{array}{l}\text { Instruments/methodological } \\
\text { approach }\end{array}$ & Country \\
\hline \multicolumn{6}{|c|}{ Domain-general implicit theories } \\
\hline $\begin{array}{l}\text { Compagnoni } \\
\text { et al. }\end{array}$ & $\begin{array}{l}\text { Implicit theories about } \\
\text { willpower }\end{array}$ & $\begin{array}{l}147 \text { kindergarteners } \\
\left(M_{\text {age }}=6.47 \text { years }\right)\end{array}$ & $\begin{array}{l}\text { Behavioural self-regulation, } \\
\text { learning goals }\end{array}$ & $\begin{array}{l}\text { Self-report questionnaire with a 5- } \\
\text { point semantic differential scale, } \\
\text { teacher ratings } \\
\text { Regression analysis }\end{array}$ & Switzerland \\
\hline Liu & Implicit theories of intelligence & $\begin{array}{l}1,201 \text { students }\left(M_{\text {age }}=\right. \\
14.68 \text { years }) \text { from } \\
\text { secondary schools }\end{array}$ & $\begin{array}{l}\text { Achievement goals, intrinsic } \\
\text { motivation, mathematics test } \\
\text { scores }\end{array}$ & $\begin{array}{l}\text { Self-report questionnaire with a 6- } \\
\text { point Likert scale, structural } \\
\text { equation modelling }\end{array}$ & Singapore \\
\hline Muenks et al. & $\begin{array}{l}\text { Intelligence mindsets, failure } \\
\text { mindsets, effort mindsets }\end{array}$ & $\begin{array}{l}304 \text { undergraduate } \\
\text { engineering students } \\
\left(M_{\text {age }}=19.56 \text { years }\right)\end{array}$ & $\begin{array}{l}\text { Perceptions of their professors' } \\
\text { mindsets, perceptions of peers' } \\
\text { mindsets, motivation, sense of } \\
\text { belonging, academic choices }\end{array}$ & $\begin{array}{l}\text { Self-report questionnaire with a 6- } \\
\text { point Likert scale, } t \text {-tests, regression } \\
\text { analyses }\end{array}$ & United States \\
\hline $\begin{array}{l}\text { Montagna } \\
\text { et al. }\end{array}$ & Implicit theories of intelligence & $\begin{array}{l}77 \text { university pre-service } \\
\text { teacher students }\left(M_{\text {age }}=\right. \\
21.6 \text { years })\end{array}$ & $\begin{array}{l}\text { Academic self-concept, coping- } \\
\text { ability appraisal, cognitive stress } \\
\text { appraisal }\end{array}$ & $\begin{array}{l}\text { Self-report questionnaire with a 6- } \\
\text { point Likert scale, computer-based } \\
\text { mindset intervention }\end{array}$ & Germany \\
\hline $\begin{array}{l}\text { Bauer and } \\
\text { Hannover }\end{array}$ & Implicit theories of excellence & $\begin{array}{l}663 \text { university students } \\
\left(M_{\text {age }}=24.27 \text { years }\right)\end{array}$ & $\begin{array}{l}\text { Sense of belonging, effects of } \\
\text { gender and ethnicity }\end{array}$ & $\begin{array}{l}\text { Self-report questionnaire with a } 7 \text { - } \\
\text { point Likert scale, experimental } \\
\text { manipulation, ANOVA }\end{array}$ & Germany \\
\hline Yan and Wang & $\begin{array}{l}\text { Intelligence mindset, difficulty- } \\
\text { as-importance, difficulty-as- } \\
\text { impossibility, ease-as- } \\
\text { possibility, ease-as-triviality }\end{array}$ & $\begin{array}{l}366 \text { college } \\
\text { undergraduates' } \\
\text { students (18-41 years) }\end{array}$ & $\begin{array}{l}\text { Course interest and importance, } \\
\text { achievement goals, study } \\
\text { strategies }\end{array}$ & $\begin{array}{l}\text { Self-report questionnaire with a 6- } \\
\text { point Likert scale, person-centred } \\
\text { approach, latent profile analysis, } \\
\text { regression analyses }\end{array}$ & United States \\
\hline Levinthal et al. & Implicit theories about learning & $\begin{array}{l}19 \text { parents }\left(M_{\text {age }}=\right. \\
43.84 \text { years) of first- to } \\
\text { sixth-grade children }\end{array}$ & $\begin{array}{l}\text { Parental engagement with their } \\
\text { children's learning at home }\end{array}$ & $\begin{array}{l}\text { Qualitative study, semi-structured } \\
\text { interviews } \\
\text { content-analysis method }\end{array}$ & $\begin{array}{l}\text { Finland and } \\
\text { Portugal }\end{array}$ \\
\hline \multicolumn{6}{|c|}{ Domain- or ability-specific implicit theories } \\
\hline Law et al. & $\begin{array}{l}\text { Gender stereotypes beliefs } \\
\text { about STEM }\end{array}$ & 143 children (5-12 years) & $\begin{array}{l}\text { Age, gender, experimental } \\
\text { conditions }\end{array}$ & $\begin{array}{l}\text { Self-report questionnaire with a } 10 \text { - } \\
\text { point Likert scale, experimental } \\
\text { manipulation, ANOVA }\end{array}$ & United Kingdom \\
\hline Karlen et al. & $\begin{array}{l}\text { Implicit theories about self- } \\
\text { regulated learning }\end{array}$ & $\begin{array}{l}244 \text { secondary school } \\
\text { students }\left(M_{\text {age }}=\right. \\
14.57 \text { years })\end{array}$ & $\begin{array}{l}\text { Self-concept about self- } \\
\text { regulated learning, emotions } \\
\text { about learning } \\
\text { strategy knowledge, academic } \\
\text { achievement }\end{array}$ & $\begin{array}{l}\text { Self-report questionnaire with a 5- } \\
\text { point semantic differential scale, } \\
\text { strategy knowledge test, path } \\
\text { analysis }\end{array}$ & Switzerland \\
\hline Wolff & $\begin{array}{l}\text { Math-related gender } \\
\text { stereotypes }\end{array}$ & $\begin{array}{l}1,424 \text { secondary school } \\
\text { students }\left(M_{\text {age }}=\right. \\
15.1 \text { years })\end{array}$ & Math self-concept & $\begin{array}{l}\text { Self-report questionnaire with a } 6 \text { - } \\
\text { point Likert scale, multiple groups } \\
\text { two-level structural equation } \\
\text { modelling }\end{array}$ & Germany \\
\hline $\begin{array}{l}\text { Rechsteiner } \\
\text { et al. }\end{array}$ & $\begin{array}{l}\text { Implicit theories of school } \\
\text { improvement abilities }\end{array}$ & $\begin{array}{l}1,483 \text { elementary school } \\
\text { teachers }\left(M_{\text {age }}=43.31\right. \\
\text { years })\end{array}$ & $\begin{array}{l}\text { Collective regulation activities, } \\
\text { being on the right track }\end{array}$ & $\begin{array}{l}\text { Self-report questionnaire with a 6- } \\
\text { point semantic differential scale, } \\
\text { structural equation modelling }\end{array}$ & Switzerland \\
\hline \multicolumn{6}{|c|}{ Domain-general and -specific implicit theories } \\
\hline Puusepp et al. & $\begin{array}{l}\text { Intelligence mindsets, math } \\
\text { mindsets }\end{array}$ & $\begin{array}{l}97 \text { elementary school } \\
\text { students }\left(M_{\text {age }}=\right. \\
8.94 \text { years })\end{array}$ & $\begin{array}{l}\text { Reactions to negative feedback } \\
\text { in mathematics }\end{array}$ & $\begin{array}{l}\text { Self-report questionnaire with a 6- } \\
\text { point Likert scale, neuroscientific } \\
\text { experiment, computer-based math } \\
\text { task }\end{array}$ & Finland \\
\hline Su et al. & $\begin{array}{l}\text { Intelligence mindsets, failure } \\
\text { beliefs in math }\end{array}$ & $\begin{array}{l}466 \text { fifth graders } \\
\text { (10-12 years) }\end{array}$ & $\begin{array}{l}\text { Math self-efficacy, math } \\
\text { achievement }\end{array}$ & $\begin{array}{l}\text { Self-report questionnaire with a 6- } \\
\text { point Likert scale, math exam, } \\
\text { structural equation modelling }\end{array}$ & China \\
\hline $\begin{array}{l}\text { Stern and } \\
\text { Hertel }\end{array}$ & $\begin{array}{l}\text { Implicit theories of intelligence, } \\
\text { failure beliefs, implicit theories } \\
\text { about self-regulation }\end{array}$ & $\begin{array}{l}137 \text { parents }\left(M_{\text {age }}=\right. \\
37.42 \text { years }) \text { of pre- } \\
\text { schoolers }\end{array}$ & $\begin{array}{l}\text { Failure beliefs, goal orientation, } \\
\text { co-regulatory strategies }\end{array}$ & $\begin{array}{l}\text { Self-report questionnaire with a 5- } \\
\text { point semantic differential scale, } \\
\text { person-centred perspective latent } \\
\text { profile analysis }\end{array}$ & Germany \\
\hline
\end{tabular}

The purpose of this Research Topic is to provide an overview of the latest research on implicit theories. We take a multiperspective view on implicit theories and bring together current research on different implicit theories (see overview in Table 1). This Research Topic includes a total of 14 studies that address implicit theories by using empirical data from samples that were collected from different continents and cultural contexts, including Asia (China and Singapore), Europe (Finland, Germany, Portugal, Switzerland and the United Kingdom), and North America (the United States). 
Researchers assessed implicit theories in different age groups: starting from kindergarten, researchers studied children in early childhood education (Compagnoni et al.), followed by primary school students (Law et al.; Puusepp et al.; Su et al.), lower and upper secondary students (Karlen et al.; Liu; Wolff) and up to older learners at colleges and universities (Bauer and Hannover; Montagna et al.; Muenks et al.; Yan and Wang). Besides learners, researchers have also examined other groups such as teachers (Rechsteiner et al.) and parents (Levinthal et al.; Stern and Hertel). Several researchers have assessed domain-general implicit theories such as implicit theories about intelligence (Bauer and Hannover; Liu; Montagna et al.; Muenks et al.; Stern and Hertel; Su et al.; Yan and Wang), implicit theories about learning (Levinthal et al.), implicit theories about willpower (Compagnoni et al.) and implicit theories about failure, difficulty, and efforts (Muenks et al.; Su et al.; Stern and Hertel; Yan and Wang). Other researchers have taken a more domainor ability-specific approach by assessing implicit theories about selfregulated learning (Karlen et al, Stern and Hertel), implicit theories about science and math (Law et al.; Puusepp et al.; Wolff), and implicit theories about school improvement (Rechsteiner et al.). Many researchers have captured implicit theories using questionnaires; however, these questionnaires are marked by differences. While the majority of researchers have empirically assessed implicit theories as one (bipolar) construct, one researcher used a multidimensional scale (Liu) to assess entity and incremental theory separately. A group of researchers who conducted a neuroscience study applied a different approach by providing new insight into implicit theories' neural foundations (Puusepp et al.). Finally, several researchers who have conducted intervention studies have examined whether people can be triggered into adopting different implicit theories in different situations (Bauer and Hannover; Law et al.; Montagna et al.; Puusepp et al.).

\section{WHAT LESSONS WERE LEARNED FROM THE STUDIES ON THIS RESEARCH TOPIC How do Implicit Theories Support Successful Learning?}

Researchers have found several replicable associations between domain-general and domain-specific implicit theories concerning student learning and performance patterns across different age groups and cultural backgrounds. Additionally, implicit theories, for the most part, relate to students' learning and motivation, which, in turn, positively affects their academic achievement.

For young learners, Compagnoni et al.'s results indicate that Swiss kindergarteners who think of their willpower as a nonlimited resource demonstrate better behavioural self-regulation and a higher willingness to exert effort. Su et al. reported that Chinese fifth-graders' implicit theories about intelligence positively relate to students' beliefs about failure and mathematical self-efficacy, and, in turn, to mathematical achievement. Finally, Puusepp et al. found that Finnish elementary students' implicit theories about math (but not their theories about intelligence) are linked to processing feedback concerning their performance in math, which highlights the importance of domain-specific approaches.

Moving to secondary school students, Karlen et al. found a positive relationship between Swiss students' implicit theories about self-regulated learning and their self-concepts, learning emotions, strategy knowledge, and academic achievements. Finally, Lui studied Singapore students' implicit theories about intelligence. Incremental intelligence theory positively relates to mastery-approach goals and, in turn, positively associates with intrinsic motivation and test scores in mathematics.

Regarding university students, Muenks et al. examined U.S. undergraduate students' implicit theories. These students' implicit theories (intelligence, effort and failure) predicted their motivations, belonging, and choices of complex (over easy) tasks, even controlling for gender and prior achievements. For another study that originated in the United States, Yan and Wang used person-centred latent profiles to categorise profiles based on different implicit beliefs (ease and difficulty implicit theories and implicit theories about intelligence). They found that students who endorse motivationincreasing implicit theories are more likely to hold masteryapproach goals. However, implicit theories' profiles do not directly relate to strategy use, but goal orientation does.

\section{Are There Differences Between Implicit Theories in Groups of Students?}

We have reviewed if the studies in this Research Topic point out systematic differences between children and students concerning their implicit theories. The results demonstrate that lowachieving kindergartners from Switzerland reported more often that willpower is a limited resource (Compagnoni et al.). Similarly, Swiss secondary school students in lower academic tracks claimed more often that their abilities to self-regulate learning are relatively unchangeable rather than malleable (Karlen et al.). Moreover, several researchers reported gender differences. The results might differ depending on whether an ability is seen as more feminine or masculine (stereotype). For example, $\mathrm{Su}$ et al. wrote that Chinese boys have significantly higher mean levels of implicit theories about intelligence and selfefficacy in math than Chinese girls do. Wolff found similar results in Germany: boys demonstrated higher mathematical selfconcepts than girls did, and they also held a slightly stronger belief in the stereotype that favours boys in math. Law et al. reported that children from the United Kingdom demonstrated in-group bias in relation to their gender regarding implicit theories about space science. Finally, Karlen et al. found that in a group of Swiss students, the girls reported a higher selfconcept for self-regulated learning than the boys did. However, these differences were not exhibited for the implicit theories about self-regulated learning. These results indicate that particular groups of learners (students with learning difficulties and students who are affected by stereotypes) are at risk of having less adaptive implicit theories, which could harm their future development. Therefore, future researchers may want to examine whether group differences exist. 


\section{Do Interventions That Aim to Change Implicit Theories Work?}

Interventions that aim to change implicit theories build on the idea that ability can be developed and that people can develop their abilities actively through the actions they take. The three intervention studies in this Research Topic involve different intervention approaches, various implicit theories and different populations. The researchers demonstrated that people can be triggered to adopt different implicit theories (Bauer and Hannover; Law et al.; Montagna et al.). Law et al. reported that a group of children who were exposed to an incremental theory intervention reported significantly less gender stereotyping about STEM than the children who were members of the control group. Montagna et al. found that even a one-time computerised intervention of $25 \mathrm{~min}$ that focuses on implicit theories about intelligence (an incremental theory message or a saying-is-believing exercise) positively impacts teachers' and students' incremental theories (but not their stress appraisal). Bauer and Hannover developed an intervention using manipulated advertising material and tested its effects on university students' belonging to a "genius" organisation (implicit theories about excellence). Individuals who fit the profile of a gifted student benefited regarding their sense of belonging in the organisation as they had a fixed view of excellence in contrast to students who did not match that profile (for example, females from negatively stereotyped ethnic minority groups). Summarily, the three research groups demonstrated that when interventions on implicit theories are well-crafted and target specific groups, the probability of their effects presumably increases. However, this does not mean that interventions will work in every cultural context or for all student populations. Yeager and Dweck (2020) suggested that intervention effects might be more meaningful when individuals are actively facing challenges or setbacks (e.g., lower-achieving students or stereotype threats) and when the context provides opportunities for students to act on their implicit theories. However, there is much more to learn about heterogeneity in interventions to support students' incremental theories, especially in young children.

\section{The Socialisation of Implicit Theories: Parents' and Teachers' Implicit Theories and the Role of the Learning Context}

Where do implicit theories come from, and how are they socialised? One possible answer involves the influence of pedagogical agents' implicit theories. Parents and teachers' implicit theories might impact their learning-related coregulatory behaviours and might consequently prime leaners' implicit theories. Stern and Hertel identified three profiles of implicit theories among parents of pre-schoolers. Parents in different profiles exhibited different (adaptive) patterns that were affected by their attitudes and co-regulatory strategies. For example, parents who had high incremental theories about self-regulation displayed the most adaptive attitudes and behaviours in comparison to the others. Levinthal et al. found in their qualitative studies that most of the examined parents of young school children adhered to incremental theories. This finding aligned with acknowledging the role of effort in learning, such as pursuing following broader forms of engagement, encouraging persistence and practice, and interpreting difficulties as a natural part of learning.

Moving to the classroom context, the assumption that implicit theories that are held by significant others (e.g., classmates) might influence individual implicit theories becomes crucial. In this context, Wolff demonstrated that gender stereotypes in math that are shared by students' classmates substantially impact students' mathematical self-concepts, even beyond their individual gender stereotypes. In line with this result, Muenks revealed that the classroom context, as operationalised by students' perceptions of their professors' and peers' implicit theories, can predict their motivations, sense of belonging, and academic choices, even controlling for students' implicit theories. Taken together, the results of both studies provide essential empirical evidence that demonstrates that students' implicit theories are also influenced by how individuals experience their contexts (e.g., the social context in a classroom and the implicit theories about teachers and peers).

Rechsteiner et al. focused on teachers' implicit theories about professional abilities and the importance of those theories for school improvement as a collective learning process. They found that the majority of primary school teachers believe that professional abilities can be changed or developed. The results revealed that teachers' incremental theories about professional abilities positively relate to collective emotional-motivational regulation strategies and, in turn, to being on the right track according to school improvement guidelines. The authors noted that implicit theories might not only be necessary for an individual's development but might also be relevant for teachers' engagement in school improvement on an institutional level.

\section{CONCLUSION}

The international and inter-cultural mix of data sources, methodological approaches, and perspectives about implicit theories offers new insight into the foundations and effects of implicit theories. The studies demonstrate that implicit theories about different abilities can be assessed for individuals from a young age (kindergarteners) to adulthood and through different methodological approaches (i.e., questionnaires, interviews and neuroscience). In summary, the results demonstrate that implicit theories have the power to influence learning in different educational contexts. Adaptive implicit theories or mindsets can support students' motivations, self-regulation, efforts to learn, as well as influence their sense of belonging and coping with negative feedback. Moreover, the research in this Research Topic presents evidence that through well-crafted interventions, learners' domain-general and domain-specific implicit theories can be manipulated and thus lead to individual adaptations in their motivations, behaviours and reactions. Finally, several 
authors demonstrated that implicit theories also provide an essential framework for understanding parents' and teachers' learning-related co-regulatory behaviours.

The findings from the Research Topic point to several future directions for research. First, researchers should understand the origins of learners' implicit theories, the effects that these theories have within different groups of learners, and the socialisation practices that foster them. Second, implicit theories can be assessed from a very early age and are essential aspects of an individual's learning biography in lifelong learning. Third, parents and teachers' implicit theories might shape students' implicit theories. Consequently, helping parents and teachers create environments that support the development of incremental theories and examine the effect of mindset interventions is essential. However, mindset interventions that are administered by teachers have resulted in inconsistent success (e.g., Foliano et al., 2019). Finally, the further investigation of domain specificity or the cross-domain effects of implicit theories and their extension to other ability domains holds much potential.

Implicit theories have the power to influence learning in different educational contexts for various populations of

\section{REFERENCES}

Bostwick, K. C. P., and Becker-Blease, K. A. (2018). Quick, Easy Mindset Intervention Can Boost Academic Achievement in Large Introductory Psychology Classes. Psychol. Learn. Teach. 17 (2), 177-193. doi:10.1177/ 1475725718766426

Burnette, J. L., Hoyt, C. L., Russell, V. M., Lawson, B., Dweck, C. S., and Finkel, E. (2020). A Growth Mind-Set Intervention Improves Interest but Not Academic Performance in the Field of Computer Science. Soc. Psychol. Personal. Sci. 11 (1), 107-116. doi:10.1177/1948550619841631

Compagnoni, M., Karlen, Y., and Maag Merki, K. (2019). Play it Safe or Play to Learn: Mindsets and Behavioral Self-Regulation in Kindergarten. Metacognition Learn. 14 (3), 291-314. doi:10.1007/s11409-019-09190-y

Foliano, F., Rolfe, H., Buzzeo, J., Runge, J., and Wilkinson, D. (2019). Changing Mindsets: Effectiveness Trial. Millbank: National Institute of Economic and Social Research.

Gunderson, E. A., Hamdan, N., Sorhagen, N. S., and D'Esterre, A. P. (2017). Who Needs Innate Ability to Succeed in Math and Literacy? Academic-domainspecific Theories of Intelligence about Peers versus Adults. Dev. Psychol. 53 (6), 1188-1205. doi:10.1037/dev0000282

Hertel, S., and Karlen, Y. (2021). Implicit Theories of Self-regulated Learning: Interplay with Students' Achievement Goals, Learning Strategies, and Metacognition. Br. J. Educ. Psychol. 91 (3), 972-996. doi:10.1111/bjep.12402

Lee, J., Lee, H. J., Song, J., and Bong, M. (2021). Enhancing Children's Math Motivation with a Joint Intervention on Mindset and Gender Stereotypes. Learn. Instruction 73, 101416. doi:10.1016/j.learninstruc.2020.101416

Mangels, J. A., Butterfield, B., Lamb, J., Good, C., and Dweck, C. S. (2006). Why Do Beliefs about Intelligence Influence Learning success? A Social Cognitive learners. Implicit theories thus build a framework for examining individual differences in learning and academic outcomes. The evidence reveals the meaningful heterogeneity of the effects of implicit theories for learning of different students' populations through various studies in this Research Topic. The researchers have also demonstrated that well-crafted interventions could modify implicit theories. Furthermore, implicit theories also provide an essential framework for understanding parents' and teachers' learning-related coregulatory behaviours. The more we learn about why and in what context implicit theories are meaningful, the more we can refine theoretical frameworks, improve measures of implicit theories, and develop targeted intervention programs. This will eventually also help increase pedagogical agents' awareness of the importance of implicit theories and support tomorrow's learning.

\section{AUTHOR CONTRIBUTIONS}

All authors listed have made a substantial, direct and intellectual contribution to the work and approved it for publication.

Neuroscience Model. Soc. Cogn. Affect Neurosci. 1 (2), 75-86. doi:10.1093/ scan/nsl013

OECD (2021). Sky's the Limit: Growth Mindset, Students, and Schools in PISA. Paris: OECD.

Sisk, V. F., Burgoyne, A. P., Sun, J., Butler, J. L., and Macnamara, B. N. (2018). To what Extent and under Which Circumstances Are Growth Mind-Sets Important to Academic Achievement? Two Meta-Analyses. Psychol. Sci. 29 (4), 549-571. doi:10.1177/09567976177397010.1177/ 0956797617739704

Yeager, D. S., and Dweck, C. S. (2020). What Can Be Learned from Growth Mindset Controversies. Am. Psychol. 75 (9), 1269-1284. doi:10.1037/ amp0000794

Conflict of Interest: The authors declare that the research was conducted in the absence of any commercial or financial relationships that could be construed as a potential conflict of interest.

Publisher's Note: All claims expressed in this article are solely those of the authors and do not necessarily represent those of their affiliated organizations, or those of the publisher, the editors and the reviewers. Any product that may be evaluated in this article, or claim that may be made by its manufacturer, is not guaranteed or endorsed by the publisher.

Copyright (c) 2021 Karlen and Hertel. This is an open-access article distributed under the terms of the Creative Commons Attribution License (CC BY). The use, distribution or reproduction in other forums is permitted, provided the original author(s) and the copyright owner(s) are credited and that the original publication in this journal is cited, in accordance with accepted academic practice. No use, distribution or reproduction is permitted which does not comply with these terms. 